\title{
TRANSFORMASI KULTURAL MENUJU DEMOKRASI SUBSTANSIAL
}

Oleh:

\section{Sugeng Bayu Wahyono}

\begin{abstract}
Abstrak
Demokrasi diyakini telah membawa perubahan politik dan kultural. Namun, sebenarnya masyarakat telah mempunyai tradisi yang sesuai dengan prinsip demokrasi tersebut. Nilai-nilai demokrasi seperti menghargai pendapat orang lain, toleransi, dan keterbukaan, terus hidup laten di kalangan akar rumput. Kondisi tersebut menunjukkan potensi akar rumput sebagai agen pembaruan menuju masyarakat transformatif secara kultural ke arah demokratisasi sepertinya jauh lebih besar, dibandingkan dengan kelas menengah. Ini artinya, budaya politik kalangan akar rumput yang bertingkah laku politik yang bersih justru perlu ditiru oleh kalangan elite politik. Tingkah laku politik yang bersih akan menghasilkan budaya politik yang menjunjung tinggi nilai kejujuran sebagaimana yang ditunjukkan oleh kalangan akar rumput pada level komunitas RT-RW justru perlu ditiru oleh elit politik pada level politik nasional
\end{abstract}

Kata kunci: transformasi, agen, akar rumput

\begin{abstract}
Democracy is believed already bring social and cultural changes. However, actually people already has tradition that is approriate with principles of democracy. Principles of democracy such as respect another people argument, tolerance and inclusiveness, latently lives in grassroots people. This condition shows bigger potentiality from grassroots people as an renewal agent towards culturally transformative society into democratization rather than people from middle class. This means clean political culture of grassroots people should become a model for political elite. Clean political behavior will produce culture of politics that uphold the value of honesty as shown by grassroots people in community level (RT/RW), this should become a model for political elite in nasional level.
\end{abstract}

Keywords : transformation, agent, grassroots 


\section{A. Pendahuluan}

Meskipun terdapat sisi kelemahan, tetapi bagaimanapun demokrasi tetap dianggap sebagai sistem yang terbaik untuk penyelenggaraan pemerintahan pada suatu negara. Dengan pilihan demokrasi, kedaulatan berada di tangan rakyat, hak-hak sipil terjaga, suara dari bawah tersalur, dan Hak Asasi Manusia (HAM) dijamin. Karena itu, hampir di setiap negara bangsa mempunyai cita-cita menyelenggarakan sistem pemerintahan yang demokratis, kendatipun dalam pencapaiannya sering kali harus ditempuh dengan perjuangan panjang. Bahkan tidak sedikit, negara yang harus membayar dengan ongkos kemanusian tinggi tatkala memperjuangkan demokrasi dari penindasan rezim otoriter, yaitu jatuhnya korban jiwa dalam jumlah cukup signifikan.

Sejarah perjalanan sebuah bangsa di dunia itu sendiri senantiasa diwarnai oleh tarik-menarik antara kekuatan otoritarian berhadapan dengan kekuatan pro demokrasi, dan pada akhirnya demokrasi keluar sebagai pemenang. Fukuyama menganalisis perkembangan dunia, bahwa setelah jatuhnya negara-negara komunis yang ditandai runtuhnya Uni Soviet, maka demokrasi liberal berdiri sendiri tanpa ada pesaing, dan sejarah perjalanan dunia telah berakhir dengan kemenangan demokrasi. Fukuyama beranggapan bahwa kaum nasionalis irasional tidak bisa bertahan hidup menuju demokrasi. ${ }^{1}$ Meski tesis Fukuyama ini ditentang oleh Avineri² yang mengatakan bahwa nasionalisme, dan bukan demokrasi liberal yang ternyata sukses menuju komunisme, yang berarti sejarah masih belum berakhir; tetapi bagaimanapun demokrasi liberal tetap menjadi pilihan utama.

Di Indonesia sendiri sejak memperoleh pengakuan internasional sebagai negara merdeka dan berdaulat, perjalanan sejarah demokrasi juga mengalami pasang-surut. Pada awal kemerdekaan, dengan dipelopori oleh kaum terdidik, ide demokrasi terus diintrodusir sebagai dasar bagi sistem pemerintahan yang dicita-citakan. Ketika kemudian Soekarno terpilih sebagai kepala negara dan kepala pemerintahan untuk pertama kalinya, spirit demokrasi terasa begitu menguat dan puncaknya terselenggaranya Pemilu 1955 yang berjalan amat demokratis. Akan tetapi setelah Soekarno menerapkan apa yang ia sebut sebagai demokrasi terpimpin, maka seketika itu demokrasi menjadi surut hingga kekuasaannya jatuh ke tangah rezim militer pimpinan Soeharto, dan Indonesia memasuki masa yang dikenal dengan Orde Baru.

Pada masa Orde Baru, demokrasi semakin terasa surut sebagai konsekuensi pilihan sadar Soeharto yang lebih memilih sistem politik otoriter dengan kekuasaan politik memusat
1 Francis Fukuyama, 1992, The End of History andThe Last Man, New York: Free Press. Shlomo Avineri, 1992, The Return to History:

2The Breakup of the Soviet Union, Brookings Review 10; dan uraian lebih lengkap bisa dilihat Ghia Nodia,
Nationalism and Democracy, dalam Larry Diamond and Marc F. Plattner (ed) Nationalism, Ethnic Conflict, and Democracy, London: Johns Hopkins University Press. 1994. 
Jurnal Pemikiran Sosiologi Volume 1 No.1, 2012

Sugeng Bayu Wahyono

Transformasi Kultural Menuju Demokrasi Substansial

pada eksekutif. Seluruh aspek legalitas diupayakan sedemikian rupa untuk melegitimasi sentralisasi kekuasaan yang berporos pada Presiden. Dengan menerapkan politik pemusatan, Soeharto melakukan kontrol secara ketat terhadap seluruh kekuatan masyarakat yang terorganisir, tidak terkecuali partai politik. Pelan tapi pasti, Soeharto melakukan penyederhanaan Parpol melalui strategi fusi dengan menerapkan asas tunggal Pancasila. Negara tampil begitu perkasa, yang melakukan politik pengendalian dan politik perizinan terhadap aktivitas sosial politik masyarakat, sehingga tidak ada satu kekuatan alternatif yang mampu mengimbangi kekuasaan eksekutif.

Para teoritisi menjelaskan bahwa fenomena seperti itu merupakan kas negara korporasi. ${ }^{3} \mathrm{Di}$ bawah kendali Soeharto, Indonesia merupakan negara yang korporatis. Peran negara di masa Orde Baru begitu dominan di segala aspek kehidupan, dan secara efektif menjalankan fungsi kontrol terhadap masyarakat yang eksesnya terhadap kehidupan demokrasi sangat buruk. Melalui mekanisme politik pengendalian, negara masuk ke berbagai wilayah publik yang perlahan tapi pasti mampu melumpuhkan berbagai kekuatan pro demokrasi. Partai Politik, Ormas, lembaga legislatif, pers, organisasi profesi, mahasiswa, dan berbagai kelompok

\footnotetext{
${ }^{3}$ Negara korporatis adalah negara yang mengendalikan semua komponen kekuatan politik, baik kekuatan di seluruh lini institusi negara sendiri maupun kelompokkelompok masyarakat diluarnya. Uraian lengkap dapat dilihat pada Alfred Stepan, 1978, State and Society: Peru in Corporative Perspective. New Jersey: Princetton University Press. Untuk klasifikasi negara-negara lihat juga Maswardi
}

penekan berhasil dijinakkan dan bahkan adakalanya dilumpuhkan dengan kekuatan represif.

Sudah bisa diduga, dalam situasi politik seperti itu maka kehidupan demokrasi mengalami masa surut, dan Parpol sebagai salah satu pilar demokrasi eksistensinya sangat lemah. Parpol tidak lebih sekadar ornamen politik, yang hanya berfungsi untuk melegitimasi kehendak eksekutif dalam proses penyelenggaraan pemerintah yang penuh formalisme. Pemilu sekadar menjalankan rutinitas politik yang meskipun berhasil terselenggara secara tertib, tetapi kualitas demokrasinya sangat rendah, dan bahkan cenderung anti-demokrasi.

Setelah Soeharto jatuh, Indonesia memasuki negara transisi demokrasi, dan Pemilu kembali ke multipartai dengan sistem semi-distrik. Secara sederhana masa transisi demokrasi dipahami sebagai proses perubahan menuju kualitas sistem politik dan pemerintahan yang lebih demokratik. ${ }^{4}$ Pada Pemilu 1999 PDI-P tampil sebagai pemenang, dan Pemilu 2004 Golkar kembali tampil sebagai pemenang.

Setelah Indonesia memasuki apa yang disepakati sebagai era reformasi, kekuasaan tidak lagi terkonsentrasi pada negara dengan pelaku utama militer, birokrasi, dan kaum konglomerat yang ketiganya menjadi agen kekuatan kapitalisme global, maka muncul

Rauf, "Pendekatan-Pendekatan Dalam Ilmu Politik: Studi Penjajagan", Ilmu dan Budaya. No. 7, April 1991, hlm. 524526.

4 Dikutip dari Kusnanto Anggoro, 1999, Gagasan Militer Mengenai Demokrasi, Masyarakat Madani dan Transisi Demokratik, Jakarta: CSIS, hlm.8. 
kekuatan baru yaitu elit Parpol. Kemudian elit baru inilah yang kemudian menjadi kelompokkelompok penekan yang mengontrol kebijakan negara melalui jalur politik di parlemen. Fenomena ini mengindikasikan bahwa perkembangan politik Indonesia mengalami pergeseran karakter dari negara korporasi (corporatist state), menuju negara organis (organic state). ${ }^{5}$

Dalam situasi negara seperti itu, penjelasan teoretik yang berangkat dari konsep hubungan negara-masyarakat, tidak lagi relevan. Berdasarkan kenyataan empiris yang berkembang, maka kekuasaan oligarki lebih dapat menjelaskan. Keberadaan kekuasaan oligarki masih tetap kuat merupakan konsekuensi logis dari tidak tuntasnya pergantian elite bentukan Orde Baru. Mereka ini memang lahir dari sistem politik Orde Baru, dan terus melakukan penyesuaian dengan perubahan politik di Indonesia.

Munculnya BJ Habibie sebagai pengganti Soeharto pada tahun 1998 turut memperluas pertarungan berbagai kelompok, baik yang proreformasi dan pro Soeharto maupun proHabibie. Semua pertarungan ini bermuara makin rontoknya basis-basis oligarki yang dibangun oleh Soeharto. Sejak saat itu pusatpusat kekuasaan dan aset-aset ekonomi

5 Negara organis adalah negara yang posisinya dikendalikan oleh salah satu kelompok atau beberapa kelompok elit sosial. Negara organis dapat berbentuk negara fascis yang dikendalikan oleh kelompok tertentu atau perorangan seperti rezim Nazi di bawah Hitler di Jerman; dapat pula negara dijadikan alat pertarungan oleh kelompok-kelompok elit sosial untuk memperjuangkan kepentingan sempit mereka sendiri seperti negara-negara liberal Eropa Barat dan Amerika Serikat abad 17-19. Uraian strategis menjadi perebutan kekuatan politik baru. Situasi ini kemudian menjadi momentum kekuatan oligarki yang belum sepenuhnya rontok, berusaha keras untuk mempertahankan diri. Mereka ini menjadi diuntungkan karena pemerintahan baru tidak mampu menyelesaikan kasus-kasus besar utang konglomerat dan praktik KKN kelas kakap, sehingga mereka ini semakin mendominasi kembali.

Kekuatan oligarki ini kemudian ikut bermain dengan kekuatan politik baru. Hasil Pemilu 1999 yang melahirkan lima kekuatan politik besar, PDIP, Golkar, PPP, PKB, dan PAN, dan karena itu kekuatan oligarki harus beradaptasi dengan kekuatan ini. Repotnya, aktor-aktor politik baru tidak akan dapat menghilangkan kebiasaan lama, yaitu bahwa politisi baru itu terbukti melakukan hal yang sama seperti yang dilakukan Soeharto bersama oligarkinya. Kini aktor-aktor politik baru menjadikan negara sebagai sasaran penjarahan atau sapi perah. Pusat-pusat kekuasaan dan aset-aset ekonomi menjadi rebutan diantara mereka. Bagi-bagi kekuasaan adalah menu politik mereka, dan ini terjadi tidak hanya di pusat pemerintahan, tetapi juga di daerah-daerah memanfaatkan era otonomi daerah. ${ }^{6}$ Kekuatan oligarki ini terbukti mampu beradaptasi dengan perkembangan

lengkap dapat dilihat pada Alfred Stepan, 1978, State and Society: Peru in Corporative Perspective. New Jersey: Princenton University Press. Untuk klasifikasi negaranegara lihat juga, Maswardi Rauf, "Pendekatan-Pendekatan Dalam Ilmu Politik: Studi Penjajagan", Ilmu dan Budaya No.7, April 1991, hlm. 524-526.

${ }^{6}$ Lihat Richard Robinson dan Vedi R Hadiz, 2004, Reorganizing Power in The Politics of Oligarchy in an Age of Markets, London and New York: Routledge Curzon. 
politik baru, termasuk membangun koalisi dengan kekuatan reformis.

Tulisan ini akan mencoba melihat bagaimana dinamika kehidupan politik pada era pasca Orde Baru dengan berbagai kompleksitas permasalahan di seputar isu politik Indonesia kontemporer, melalui perspektif sosial budaya. Harapannya dengan memberikan penjelasan secara sosio-kultural dapat membantu mengidentifikasi permasalahan fundamental dalam upaya membangun Indonesia sebagai negara demokrasi yang substansial.

\section{B. Perspektif Budaya Politik}

Terdapat beberapa cara dalam upaya menjelaskan fenomena politik, akan tetapi yang paling sederhana dapat dibedakan dengan pendekatan struktural dan kultural. Penjelasan ekonomi politik misalnya, termasuk bersifat strukturalis yang mencoba menjelasakan dengan mengaitkan antara persoalan politik dengan masalah ekonomi. Ada juga pendekatan lain yang lebih cenderung strukturlis yaitu dengan menjelaskan fenomena politik dari analisis hubungan negara dan masyarakat dengan kata kunci civil society. Pendekatan ini cukup mampu menjelaskan fenomena politik di era Orde Baru dengan negara berposisi sebagai variabel utama dalam mempengaruhi berbagai peristiwa politik yang ada.

Sementara pendekatan yang bersifat kulturalis meyakini bahwa kultur lebih dominan dalam mempengaruhi berbagai fenomena politik.
Untuk menyebut beberapa teoretisi yang masuk kategori pendukung kulturalis yang pernah melakukan studi di Indonesia antara lain, Don Emerson, Ben Anderson, Clifford Geertz, Bill Liddle, Karl Jackson, dan Harold Crouch. Sementara itu, suatu studi yang bersifat kulturalis adalah Gabriel Almond dan Sidney Verba, ketika keduanya melakukan kajian di lima negara yang kemudian melahirkan buku yang sangat berpengaruh pada dekade 1970-an, The Civic Culture.

Budaya politik, kata Almond dan Verba, merupakan sikap individu terhadap sistem politik dan komponen-komponennya, juga sikap individu terhadap peranan yang dimainkan dalam sebuah sistem politik. Budaya politik tidak lain adalah orientasi psikologis terhadap obyek sosial, dalam hal ini sistem politik yang kemudian mengalami proses internalisasi ke dalam bentuk orientasi yang bersifat kognitif, afektif, dan evaluatif.

Orientasi yang bersifat kognitif merupakan pemahaman dan keyakinan individu terhadap sistem politik dan atributnya, seperti tentang ibukota negara, lambang negara, kepala negara, batas-batas negara, mata uang yang dipakai, dan sebagainya. Sementara itu orientasi afektif menyangkut ikatan emosional yang dimiliki individu terhadap sistem politik. Jadi menyangkut feelings terhadap sistem politik. Sedangkan orientasi yang bersifat evaluatif menyangkut kapasitas individu dalam rangka memberikan penilaian terhadap sistem politik yang sedang berjalan dan bagaimana peranan individu di dalamnya. 
Dalam suatu masyarakat yang sikap dan orientasi politiknya didominasi oleh karakteristik yang bersifat kognitif akan terbentuk budaya politik yang parokial. Sementara, dalam sebuah masyarakat yang sikap dan orientasi politiknya diwarnai oleh karakteristik yang bersifat afektif, akan terbentuk budaya politik yang bersifat subyektif. Akhirnya, masyarakat yang memiliki kompetensi politik yang tinggi, di mana warga masyarakat mampu memberikan evaluasi terhadap proses politik yang sedang berjalan, akan terbentuk sebuah budaya politik yang bersifat partisipatif.7

Almond dan Verba mengemukakan tesis bahwa budaya politik yang demokratik, dalam hal ini budaya politik yang partisipatif, akan mendukung terbentuknya sistem politik yang demokratik dan stabil. Ia mengemukakan bahwa berdasarkan hasil penelitiannya di sejumlah negara yaitu di AS, Inggris, Jerman, Italia, dan Meksiko, menemukan di negara-negara yang mempunyai budaya politik tinggi akan menopang demokrasi yang stabil. Sebaliknya, negara-negara yang memiliki budaya politik rendah tidak mendukung terwujudnya sistem politik demokratik yang stabil.

Apabila menggunakan model dari Almond dan Verba, dan kemudian melihat fenomena budaya politik di Indonesia, maka banyak yang sepakat bahwa dominasi sikap dan orientasi politik yang parokial masih terasa hingga sekarang.

7 Lihat Gabriel A Almond dan Sidney Verba, 1963, The Civic Culture, Princenton, New Jersey: Princenton University Press.
Meskipun format dan struktur politik sudah jauh lebih demokratis jika dibandingkan dengan era Orde Baru, tetapi kultur politiknya masih belum mengalami transformasi, karena itu demokrasi di Indonesia masih dalam tataran prosedural, belum merupakan demokrasi yang substansial. Pernyataan seperti itu semakin kuat jika dikaitkan dengan karakter sosiologis masyarakat Indonesia yang masih lebih terasa sebagai masyarakat patrimonialistik. Dalam masyarakat seperti itu, maka persoalan budaya politik menjadi lebih penting. Relasi dalam pergaulan sosial yang masih didasarkan pada pola patron-klien, di mana orang kecil akan banyak mengikuti apa yang dilakukan oleh mereka yang dianggap menjadi panutan, tanpa mempersoalkan sendiri apakah yang dilakukan oleh panutan itu benar atau salah. Dalam suatu masyarakat dengan pola dasar patron-klien, suatu budaya politik yang sangat tergantung kepada tingkah laku elit politiknya. Jika tingkah laku politik para elit politik baik, maka para pengikutnya juga baik, dan begitu sebaliknya.

Masih dominannya budaya politik seperti itu mempunyai implikasi terhadap kesulitan dan mendorong terjadinya transformasi menuju civil society. Demokrasi kemudian hanya pada tataran bentuk, sementara perilaku warga masih jauh dari nilai demokrasi. Budaya politik dalam organisasi politik seperti Parpol pun juga sangat terasa nuansa patrimonialistiknya. Kondisi ini semakin mapan, ketika lahirnya berbagai parpol 
justru merupakan cermin dari karakteristik sosio-kultural masyarakatnya. Karena itu, parpol yang bermunculan masih berakar pada basis ideologis dan politik aliran.

Dengan demikian, baik secara struktural maupun kultural, parpol di Indonesia masih mengedepankan ciri primordialistik yang menjadi faktor penyulit bagi upaya membangun sistem pemerintahan yang demokratis dan stabil. Birokrasi parpol pun lebih memberi kewenangan dan bahkan konsentrasi kekuasaan kepada elit politik, ketimbang misalnya memberikan peluang bagi penguatan daya tawar basis konstituennya. Proses pencalonan pemimpin nasional, pemimpin daerah dalam Pilkada, dan penyusunan daftar urut Caleg, masih sangat terasa dominasi elit politik, dan bukan melalui proses dari bawah. Rakyat hanya menjadi obyek Parpol yang merepresentasikankepentingan elit politik, dan kemudian dijadikan alat legitimasi untuk memperoleh kekuasaan. Caranya tidak diperoleh melalui tawaran program yang rasional dan berorientasi kepada pelayanan rakyat, tetapi dimobilisasi melalui sentimen primordialistik, seperti etnis, agama, dan kedaerahan. Dengan demikian, kemunculan banyak Parpol dalam sepuluh tahun terakhir ini tidak berarti mendorong terciptanya sistem politik demokratis dan stabil, tetapi justru yang terjadi sebaliknya, yaitu elitis, pragmatik, dan anarkis yang semuanya anti nilai demokrasi.

8 Lihat Brian Barry, 1970, Sociologists, Economists, and Democracy. Chicago: University of Chicago Press.
Tesis Almond dan Verba ini telah banyak dikritik, antara lain oleh Brian Barry yang mengatakan, bahwa dengan menggunakan "teori ekonomi tentang demokrasi" hasilnya ternyata membuktikan bahwa struktur politiklah yang melahirkan sikap-sikap yang disebut budaya politik tersebut. 8 Sementara Arend Lijphart mengatakan, bahwa ketika kita berbicara tentang kognisi, sebenarnya kita tengah berbicara pengaruh struktur politik (realitas) yang kemudian dipersepsikan oleh masyarakat dan akhirnya menggumpal menjadi kognisi (kultur) yang kita maksud. ${ }^{9}$

Kritik lain terhadap tesis Almond dan Verba adalah dianggap terlalu positivistik, yang mengandaikan dinamika perkembangan budaya politik secara linier dengan pretensi bahwa di tingkat perkembangan yang paling awal lebih buruk, dan begitu seterusnya. Perspektif positivistik-linieristik seperti itu mengandaikan bahwa rakyat bersifat pasif dan hanya mengikuti saja apa yang dilakukan oleh patronasenya, karena rakyat dianggap kurang memiliki kompetensi untuk bertindak demokratis. Argumen kaum positivistik seperti itu akan senantiasa menyetujui bahwa untuk mendorong terjadinya transformasi kultural menuju sistem pemerintahan yang demokratis, maka rakyat harus memenuhi prasyarat yang telah ditentukan, misalnya harus terdidik, sejahtera secara ekonomi, dan memerlukan waktu yang cukup untuk menunggu ke tahap perkembangan yang diidolakan. Ungkapan yang khas dari

9 Arend Lijphart, 1984: Democracies: Patterns of Majoritarian and Consensus Government in Twenty-One Centuries. New Heaven Conn: Yale University Press. 
Jurnal Pemikiran Sosiologi Volume 1 No.1, 2012

Sugeng Bayu Wahyono

Transformasi Kultural Menuju Demokrasi Substansial

pandangan positivistik-linieristik itu misalnya, Amerika Serikat bisa mencapai tahap demokrasi seperti sekarang diperlukan waktu sekitar 200 tahun, sedangkan Indonesia kan baru belum lama merdeka, jadi jangan berharap terjadi demokratisasi yang berkualitas. Logika kaum positivistik memang mengandaikan perkembangan masyarakat secara linier, sama sekali tidak memperhitungkan bahwa perkembangan sejarah masyarakat yang zig-zag. Karena itu pendukung perspektif ini, termasuk Almond dan Verba, kurang menyinggung misalnya program-program lompatan ke depan.

Pandangan positivistik juga sama sekali kurang memperhitungkan adanya kemungkinan bahwa masyarakat yang berada pada tataran perkembangan awal, memiliki tradisi berdemokrasi. Ini merupakan implikasi logis dari asumsi bahwa konstruksi perkembangan masyarakat harus dimulai dari angka 1 dan kemudian berkembang ke arah angka berikutnya secara linier dengan memenuhi prasyarat yang telah ditetapkan menurut tafsir dari kelompok dominan yang menyebarkan wacana. Oleh karena itu, tidak mengandaikan adanya fakta empiris bahwa masyarakat tradisional telah melakukan tradisi berdemokrasi. Bahkan melalui penjelasan teoriteori modernisasi, masyarakat tradisional dianggap sulit berkembang menjadi masyarakat yang demokratis dan sejahtera karena terkungkung oleh nilai-nilai feodalistik dan patrimonial yang bersifat permanen. Tidak diandaikan sama sekali bahwa masyarakat tradisional yang diposisikan pada level perkembangan awal itu, mampu menjadi agen untuk kehendak bersama berubah menjadi masyarakat yang demokratis.

Itulah sebabnya, di era Orde Baru berkembang amat pesat pandangan developmentalistik yang dilandasi oleh teori-teori modernisasi dalam usaha mengubah masyarakat tradisional. Melalui program-program pembangunan sosial, ekonomi, dan politik mengandaikan masyarakat Indonesia masih sangat tertinggal dan bahkan primitif, serta senantiasa pasif. Akibatnya muncul ironi-ironi, misalnya mensosialisasikan Pancasila melalui program P-4 ke masyarakat desa, padahal secara substantif warga masyarakat desa sudah jauh lebih intens dalam mengamalkan nilai-nilai Pancasila. Model pengembangan seperti itu juga terjadi di era reformasi, ketika pemerintah dan beberapa aktivis LSM terus mendorong demokratisasi desa, padahal warga masyarakat desa jauh sebelumnya telah menerapkannya dalam berkomunitas dengan prinsip-prinsip demokrasi. Sebagai ilustrasi, warga masyarakat dalam berkomunitas di tingkat RT-RW senantiasa menggunakan mekanisme akuntabilitas, transparans, dan partisipatif sebagaimana prinsip demokarasi. Penggunaan dana bersama dalam RT-RW untuk pembangunan misalnya, senantiasa dilaporkan secara transparan di depan forum-forum pertemuan warga. Dalam perencanaan pembangunan pun, warga selalu menggunakan mekanisme dari bawah (bottom-up) dengan mempertimbangkan aspirasi warga. 
Oleh karena itu, menginginkan terjadinya transformasi kultural dalam menuju demokratisasi secara substansial melalui eksperimen model konseptualisasi pandangan kaum positivistik, mempunyai konsekuensi waktu lama. Dominasi budaya politik parokial misalnya, harus diubah lebih dulu menjadi setapak lebih maju ke arah budaya politik subyektif, dan akhirnya ke budaya politik partisipan. Untuk mengurangi budaya politik parokial, maka orientasi politik yang didominasi koginitif perlu diubah menjadi orientasi politik afektif, dan kemudian menuju orientasi politik evaluatif. Repotnya orientasi kognitif diasumsikan terjadi pada masyarakat level bawah, tidak diperhitungkan sama sekali bahwa justru orientasi politik pada level kognitif itu terjadi pada masyarakat yang berada strata kelas atas. Bahkan kalangan elit politik yang menganggap dirinya mempunyai tingkat melek politik tinggi, justru orientasi politiknya hanya terbatas pada kognisi, sementara pada tataran tindakan (action) kurang mendorong sistem demokrasi. Logikanya, mereka yang menikmati struktur sosial yang tidak adil justru adalah kaum elit, karena itu mereka cenderung memapankan. Karena itu meski mereka mempunyai kognisi demokrasi yang tinggi, dan mampu evaluasi terhadap sistem politik yang berlaku, tetapi cenderung memapankan struktursosial-politik yang tidak egalitarian. Dengan kata lain, yang sering terjadi di Indonesia, bahwa kelompok yang memiliki orientasi politik evaluatif dan berbudaya politik partisipan, justru tidak mendorong terjadinya transformasi ke arah sistem demokrasi substansial. Kelompok elit mempunyai kompetensi dalam berdemokrasi, tetapi tidak mempunyai komitmen tinggi dalam menerapkan kehidupan berdemokrasi secara lebih substansial, karena pada hakekatnya mereka lebih pro kemapanan.

\section{Essensialisme dan Konstruktivisme Budaya}

Budaya politik juga bisa dijelaskan dari perspektif esensialisme dan konstruktivisme budaya. Pandangan kaum esensialis mengatakan bahwa budaya politik adalah seperangkat nilai, norma dan kebiasaan yang menjadi dasar bagi tingkah laku para elit politik. Seterusnya diandaikan pula bahwa budaya politik tersebut didasarkan pada nilai-nilai budaya dominan yang sedang berlaku. Kaum esensialisme budaya mengandaikan bahwa nilai, norma, dan ketentuan normatif lainnya adalah sesuatu yang baku, tetap, dan permanen. Berangkat dari asumsi itu, maka kubu ini percaya jika ada tingkah laku politik yang tidak sesuai dengan seperangkat rumusan normatif itu maka terjadi penyimpangan budaya politik. Pandangan ini mengandaikan bahwa warga negara bersifat pasif, selalu mengikuti ketentuan normatif, dan tidak mampu menjadi agen untuk melakukan perubahan.

Mengikuti pengertian seperti itu, maka budaya politik tidak lain dari nilai dan kebiasaan yang berkembang di kalangan elit politik, dan menjadi semacam sub-kultur dalam kalangan ini. Masalahnya timbul karena nilai-nilai dan 
kebiasaan tersebut dianut oleh sekelompok orang yang relatif berkuasa dan berpengaruh secara politik. Akibatnya, nilai-nilai, pandangan, kebiasaan dan tingkah laku kelompok sosial ini dengan mudah menyebar, diikuti dan diterima oleh kalangan masyarakat yang lebih luas. Dengan demikian, kalau dalam bidang ekonomi gaya hidup kelas menengah kota mudah menjalar dan ditiru oleh strata sosial lainnya (juga kalau pendapatn mereka sebenarnya tidak mencukupi untuk membiayai gaya hidup tersebut), maka budaya politik adalah semacam "gaya hidup" yang dengan mudah menular kepada warga negara biasa yang tidak menjadi bagian dari elit politik (meskipun tingkah laku tersebut tidak selalu disetujuinya secara sadar).

Jika mengandaikan adanya transformasi kultural dalam perilaku politik di Indonesia menuju ke arah yang lebih demokratis, maka gugatan terhadap perspektif teoretik kaum esensialisme budaya, perlu dilakukan. Artinya, tidak mungkin ada transformasi kultural jika berkembang persepsi bahwa suatu nilai dan norma bersifat tetap, dan tidak terbuka kemungkinan untuk berubah menyesuaikan dengan realitas empiriknya. Oleh karena itu jika ingin tetap konsisten dalam diskusi tentang budaya politik, dan mengandaikan adanya transformasi kultural, maka perlu mengadopsi perspektif budaya politik dari pandangan kaum konstruktivisme budaya.

Pandangan kaum konstruktivisme budaya meyakini bahwa nilai, norma, dan kebiasaan itu bukanlah suatu yang tetap, baku, dan permanen. Dengan demikian dalam berbicara budaya politik yang perlu diperhatikan adalah, bahwa kebudayaan tidaklah hanya berisikan nilai-nilai dan norma-norma, tetapi sekaligus memberikan kemungkinan yang sama besarnya bahwa nilai dan norma tersebut diselewengkan untuk kepentingan ekonomi, kepentingan kekuasaan, atau kepentingan lainnya, dimana penyelewengan tersebut juga dengan mudah dilakukan atas nama nilai-nilai budaya yang sama. Secara teoretis dapatlah dikatakan: budaya politik tidak sekadar menjadi dasar bagi tingkah laku politik, tetapi juga dibentuk dan diberi wujud nyata oleh tingkah laku politik. Hubungan antara budaya politik dan tingkah laku politik bukanlah bahwa yang pertama mempengaruhi yang kedua, tetapi jugabahwa tingkah laku politik mempengaruhi wujud dan sifat budaya politik. Ini berarti, tingkah laku politik yang bersih akan menghasilkan budaya politik yang menjunjung tinggi nilai-nilai kejujuran, dan sebaliknya tingkah laku politik yang korup akan menghasilkan budaya politik yang dengan mudah memaafkan (dan pada akhirnya membenarkan), berbagai penyelewengan. ${ }^{10}$

Itu berarti mengandaikan adanya agen bagi upaya transformasi budaya politik yang demokratis. Persoalannya siapa yang berpotensi menjadi agen perubahan kultural ke arah perilaku politik demokratis secara masif? Dalam berbagai kajian ilmu politik, kelas menengah

10 Lihat Ignas Kleden, Budaya Politik atau Moralitas Politik?. Artikel, Kompas, 12 Maret 1998, hlm.4-5. 
sering dianggap sebagai lokomotif demokrasi yang berpotensi menarik gerbong masyarakat yang berkehendak terhadap terwujudnya sistem pemerintahan yang demokratis. Di negaranegara berkembang, kelas menengah sering diandalkan untuk tampil sebagai agen kekuatan pembaruan dari sebuah sistem politik yang anti demokrasi. Korea Selatan misalnya, sering disebut-sebut sebagai cerita sukses kelas menengah yang mampu mendorong masyarakat ke arah pemerintahan demokratis, setelah negara tersebut berada dalam pemerintahan junta militer yang otoriter.

Sementara itu, negara-negara di Eropa Timur pasca Perang Dingin merupakan contoh kegagalan negara-negara yang tidak mampu memanfaatkan momentum transisi demokrasi. Setelah runtuhnya Uni Soviet, banyak Negaranegara di kawasan Eropa Timur masuk dalam kategori negara yang memasuki transisi demokrasi, seperti Polandia, Bulgaria, Rumania, dan beberapa negara pecahan Uni Soviet. Akan tetapi transisi demokrasi di negara-negara tersebut mengalami kegagalan, atau paling tidak berjalan lamban, karena kelas menengah kurang berperan dalam mentransformasikan demokrasi ke kelas bawah. Dengan kata lain, kegagalan itu disebabkan bahwa proses demokrasi hanya berlangsung di kalangan elit politik, dan bahkan elit politik menggunakan demokrasi sebagai instrumen untuk memperoleh kekuasaan baru.

Bagaimana peran kelas menengah di Indonesia, dalam konteks membangun sistem pemerintah yang demokratis? Apa- kah kelas menengah mampu mendorong transformasi kultural ke arah politik demokratis yang substansial? Banyak studi menginformasikan bahwa kelas menengah di Indonesia relatif kurang mampu menjadi lokomotif pembaruan, termasuk dalam mendorong demokratisasi. Pada era Orde Baru kelas menengah Indonesia praktis tidak berdaya di tengah kuatnya pemberlakuan sistem politik yang otoriter. William Liddle melihat bahwa tersendatnya demokratisasi di Indonesia pada era Orde Baru adalah dikarenakan pertumbuhan kelas menengah yang tertatih-tatih. Liddle menunjuk kelas menengah itu sebagai kaum majikan, wiraswastawan atau pengusaha yang tak kelewat besar sampai menjadi konglomerat, tapi cukup makmur. Ciri mereka independen, tak bergantung pada kebaikan pemerintah. Keberadaan kelas menengah ini menurut Liddle, seharusnya dapat memperkuat posisi masyarakat ketika berhadapan dengan kekuatan negara yang otoriter. Tetapi lantaran terbatasnya kaum menengah pengusaha yang independen maka yang sering terlihat adalah kelompok yang mempunyai ketergantungan tinggi pada pemerintah. Mereka merasa tergantung karena selama ini mendapat perlindungan dan banyak kepentingan mereka yang terakomodir. Dengan demikian, maka Liddle ingin menunjukan bahwa ada hubungan antara keberadaan kelas menengah dengan berlangsungnya demokratisasi, dimana kelas menengah yang tertaih-tatih (misal di Indonesia pada waktu zaman Orde Baru) juga dapat memberikan dampak kepada tersendatnya proses demokratisasi. 
Kelas menengah yang tidak mempunyai otonomi relatif terhadap negara, karena memang kelas menengah bentukan pemerintah atau mendapat fasilitas dari pemerintah, maka kurang mampu menjadi lokomatif pembaruan. Oleh karena itu, perubahan signifikan situasi politik di Indonesia meski terdapat peran kelas menengah, tetapi secara substantif tidak cukup signifikan. Sikap kritis memang selalu ditunjukan oleh golongan kelas menengah, tetapi dalam sejarah politik di Indonesia adanya perubahan politik senantiasa tidak lepas dari faktor eksternal, yaitu perubahan atau kehendak yang dikendalikan dari dunia internasional. Sebagai ilustrasi misalnya, perubahan dari era pemerintahan kolonial Belanda ke era kemerdekaan, meski peran kaum terpelajar dan pergerakan yang dipolopori oleh kaum kelas menengah, juga tidak lepas dari perubahan konstelasi politik dunia yang dilanda oleh perang berkepanjangan di Eropa dan Asia. Demikian pula perubahan politik dari era pemerintahan Soekarno ke era Soeharto, meski peran mahasiswa cukup menonjol, akan tetapi tidak lepas dari skenario politik Amerika Serikat dalam kaitan dengan tarik-menarik kepentingan ekonomi-politik di era Perang Dingin.

Sementara itu, perubahan politik dari era Orde Baru yang otoriter ke era reformasi meski tidak mengecilkan peran kelas menengah, terutama dari kalangan mahasiswa, namun faktor eksternal dalam bentuk pengkondisian krisis ekonomi nasional yang tidak lepas dari skenario negara-negara besar, sepertinya akan sulit terjadi. Jatuhnya rezim pemerintahan Soeharto, bukan semata-mata tekanan dari dalam negeri yang digalang oleh mahasiswa, tetapi tekanan krisis ekonomi yang melibatkan permainan kekuatan kapitalisme global justru terasa lebih signifikan pengaruhnya terhadap perubahan politik di Indonesia.

Semua itu menjadi indikator lemahnya kelas menengah sebagai pendorong perubahan dalam sejarah pergulatan politik di Indonesia. Ketidakmampuan kelas menengah sebagai agen pembaruan menjadi titik lemah terjadinya ketidaklancaran proses transformasi kultural menuju sistem pemerintahan demokratis secara lebih substansial. Boleh jadi itu juga merupakan implikasi logis dari kurang intensif dan terpeliharanya hubungan kelas menengah dengan kelompok akar rumput (grassroot). Dalam momen tertentu, atau pada saat- saat krisis politik, kelas menengah sering melakukan politik representasi dengan terus berusaha mengartikulasikan suara dari kelompok akar rumput. Akan tetapi, pada saat situasi politik relatif stabil kelas menengah justru dengan cepat menjadi bagian dari elit politik yang menghuni struktur kelas atas. Pada titik itulah kemudian hubungan kelas menengah dengan kelas akar rumput menjadi renggang.

Ketika kelas menengah masuk menjadi bagian dari sistem, keterlibatan mereka dalam proses pengambilan keputusan seringkali terasa lebih pro kemapanan dan bahkan pemilik modal. Berbagai produk perundangan legislatif yang merupakan lembaga perwakilan rakyat, banyak yang tidak pro rakyat kelas bawah, tetapi justru pro kaum kapital. Meskipun proses politik 
lahirnya sebuah undang-undang pada era reformasi terasa lebih demokratis, tetapi secara substansial kurang bermuatan kepentingan rakyat. Elit politik legislatif yang kebanyakan dari kelas menengah justru mengalami erosi kepekaan terhadap aspirasi rakyat bawah. Alihalih mendengar suara aspirasi rakyat, malah di antara mereka banyak yang lupa sebagai pembawa mandat rakyat. Mereka justru kemudian menyalahgunakan kekuasaan dengan ramai-ramai melakukan penyimpangan, sehingga banyak di antara mereka terlibat kasus tindak pidana korupsi.

Sementara itu, kalangan kelas menengah yang masuk dalam jajaran eksekutif juga mengalami pencerabutan dari akar basis demokrasinya. Banyak kebijakan yang tidak pro rakyat, tetapi demi orientasi pertumbuhan mereka antusias mengundang investor asing untuk mengeksplorasi sektor ekstraktif atau pertambangan dan hasil hutan. Hampir semua Kepala Daerah dalam era Otonomi Daerah, justru menempuh kebijakan yang pro kapital dan padat modal yang berorientasi pertumbuhan ekonomi daerah. Sementara itu tidak banyak yang berusaha mengedepankan kebijakan pro rakyat yang padat karya dan beriorientasi pada pemerataan. Akibatnya, kesenjangan sosial ekonomi tetap lebar dengan elit daerah sebagai penikmat atau yang lebih dikenal sebagai penerima berkah otonomi daerah. Semua itu mengindikasikan bahwa demokrasi yang dijalankan masih berada pada tataran prosedural, dan belum berjalan secara substansial yang ditandai kesejahteraan rakyat dan proses politik yang damai.

\section{Kesimpulan: Akar Rumput sebagai Agen}

Jika kelas menengah tidak bisa menjadi tumpuhan dalam transformasi kultural ke arah demokrasi substansial, mengkonsolidasikan golongan akar rumput sebagai agen transformasi bisa menjadi tawaran menarik. Tawaran ini mengandaikan bahwa perilaku budaya politik rakyat tidak semata-mata dikendalikan oleh sistem yang berlaku atau juga tidak mengikuti perilaku budaya politik elitnya yang cenderung pro kemapanan. Budaya politik berarti bisa dilepaskan begitu saja dari nilai-nilai yang diyakini kebenarannya oleh elit politik. Di sini diandaikan terjadi proses dekonstruksi atas konstruksi yang telah terbentuk secara mapan tetang nilai-nilai yang pada prinsipnya anti demokrasi.

Dalam kehidupan politik keseharian di kalangan masyarakat sebenarnya sudah banyak melakukan praktik demokrasi. Prinsip partisipasi misalnya, dalam unit komunitas RTRW telah mengedepankan prinsip partisipasi dalam setiap melaksanakan aktivitas pembangunan di seputar lingkungan sosialnya. Prinsip mengedepankan transparansi juga telah menjadi kultur yang terus hidup dalam mekanisme pertanggungjawaban dana pembangunan yang digalang dari dana masyarakat. Perencanaan yang dibuat, kegiatan yang dilaksanakan, dan kebijakan yang diambil, semuanya dapat dipertanggungjawabkan di 
Jurnal Pemikiran Sosiologi Volume 1 No.1, 2012

Sugeng Bayu Wahyono

Transformasi Kultural Menuju Demokrasi Substansial

depan publik sesuai dengan prinsip akuntabilitas.

Jadi dalam berkomunitas pada unit pemerintahan masyarakat bawah telah mempunyai tradisi yang sesuai dengan prinsip demokrasi. Nilai-nilai demokrasi seperti menghargai pendapat orang lain, toleransi, dan keterbukaan, terus hidup laten di kalangan akar rumput. Karena itu potensi akar rumput sebagai agen pembaruan menuju masyarakat transformatif secara kultural ke arah demokratisasi sepertinya jauh lebih besar, dibandingkan dengan kelas menengah yang selama ini telah diasumsikan sebagai agen demokrasi di negara-negara berkembang. Karena itu jika fungsi kelas menengah sebagai lokomotif demokrasi kurang bisa berjalan secara efektif, maka fungsi itu bisa diambil alih oleh kalangan akar rumput.

Atau paling tidak, kalangan elit politik bisa bercermin pada budaya politik kalangan akar rumput yang telah menunjukkan perilaku politik demokrasi dalam kehidupan berkomunitas. Dengan demikian asumsi budaya politik esensialistik yang mengandaikan perilaku elit politik yang senantiasa akan ditiru oleh rakyat, sekalipun perilaku bertentangan dengan nilai demokrasi, tidak berlaku. Yang terjadi justru sebaliknya, budaya politik kalangan akar rumput yang bertingkahlaku politik yang bersih justru perlu ditiru oleh kalangan elit politik. Tingkah laku politik yang bersih akan menghasilkan budaya politik yang menjunjung tinggi nilai kejujuran sebagaiman yang ditunjukkan oleh kalangan akar rumput pada

level komunitas RT-RW justru perlu ditiru oleh elit politik pada level politik nasional. Sebaliknya, perilaku politik korup yang ditunjukkan oleh elit politik pada level nasional, tidak akan pernah ditiru oleh kalangan akar rumput dalam politik pada level desa. Itu semua menunjukkan bahwa justru kalangan akar rumput berpotensi menjadi agen dalam mendorong budaya politik bersih dan demokratis.

Dalam perspektif budaya politik yang konstruktivistik, bahwa nilai-nilai yang mendasari perilaku politik yang penuh penyimpangan akan bisa diubah oleh kalangan akar rumput. Pandangan konstruktivistik memposisikan akar rumput sebagai subyek yang aktif dan mampu melakukan dekonstruksi terhadap budaya politik mapan yang tidak bersih dan anti demokrasi. Transformasi kultural dalam berdemokrasi bisa berjalan dari bawah dengan kesediaan elit untuk bercermin dan kemudian meniru budaya politik akar rumput yang justru telah sejak lama menjalankan prinsip demokrasi secara lebih substansial.

\section{Daftar Pustaka}

Arend, Lijphart. 1984. Democracies: Patterns of Majoritarian and Consensus Government in Twenty-One Countries, New Heaven Conn: Yale University Press.

Almond, Gabriel A. dan Sidney Verba.1963. The Civic Culture. Princeton, New Jersey: Princeton University Press. 
Jurnal Pemikiran Sosiologi Volume 1 No.1, 2012

Sugeng Bayu Wahyono

Transformasi Kultural Menuju Demokrasi Substansial

Avineri, Shlomo. 1992, "The Return to History:

The Breakup of the Soviet Union",

Brookings Review 10

Barry, Brian. 1970, Sociologists, Economists and

Democracy. Chicago: University of

Chicago Press.

Fukuyama, Francis.1992. The End of History and

The Last Man. New York: Free Press.

Ghia Nodia. 1994. "Nationalism and

Democracy", dalam Larry Diamond and

Marc F. Plattner (ed) Nationalism, Ethinic

Conflict, and Democracy. London: Johns

Hopkins University Press.

Ignas Kleden, Budaya Politik atau Moralitas

Politik?, artikel, Kompas, 12 Maret 1998,

hal. 4-5.

Kusnanto Anggoro. 1999. Gagasan Militer

Mengenai Demokrasi, Masyarakat

Madani, dan Transisi Demokratik.

Jakarta: CSIS

Maswardi Rauf, "Pendekatan -Pendekatan

Dalam Ilmu Politik: Studi Penjajagan",

Ilmu dan Budaya. No. 7, April 1991

Robinson, Richard dan Hadiz, Vedi R. 2004, Reorgananising Power in The Politics of Oligarchy in an Age of Markets. London and New York: Routledge Curzon.

Stepan, Alfred. 1978. State and Society: Peru in Corporative Perspective. New Jersey: Princetton University Press. 